\title{
Measurement and prediction of digestible energy values in feedstuffs for the herbivorous fish tilapia (Oreochromis niloticus Linn.)
}

\author{
BY J.ANDERSON ${ }^{1 *}$, B. S. CAPPER ${ }^{2} \uparrow$ AND N. R. BROMAGE \\ ${ }^{1}$ Department of Molecular Sciences, University of Aston, Aston Triangle, Birmingham B4 $7 E T$ \\ ${ }^{2}$ Overseas Development Natural Resources Institute, Chatham Maritime, Chatham, Kent ME4 $4 T B$ \\ ${ }^{3}$ Institute of Aquaculture, University of Stirling, Stirling FK9 $4 L A$
}

(Received 12 October 1990-Accepted 23 November 1990)

\begin{abstract}
Digestible energy (DE) values were measured in a selection of feedstuffs for the tilapia (Oreochromis niloticus Linn.) and used to develop equations for predicting DE values of a wider range of feedstuffs from chemical analyses. Preliminary work examined the influences of substitution level in a reference diet and adaptation over time on DE values for soya-bean meal. Length of adaptation period significantly affected DE values $(P<0.01)$, but substitution level, over the range $200-600 \mathrm{~g}$ soya-bean meal $/ \mathrm{kg}$ reference diet, did not. The DE values of sixteen feedstuffs, thirteen derived from plant sources and three animal by-products, were subsequently determined. DE values for plant-derived feedstuffs were found to be higher than those quoted in the literature for trout (Oncorhynchus mykiss) and catfish (Ictalurus punctatus), whereas DE values for animal-derived feedstuffs were lower than those for trout and pigs. It was concluded that energy values quoted in tables of feed composition for other species are inaccurate when used as proxy values for tilapia. Regression equations were therefore computed using data from the present study to provide a rapid means of predicting $D E$ values of feedstuffs for tilapia. Equations using neutral-detergent fibre as an independent variable were found to predict $D E$ values of plant-derived feedstuffs reliably. Where fibre values were not used as independent variables, available carbohydrate and crude protein (nitrogen $\times 6.25$ ) were found to be useful predictors of $D E$ values. These equations offer the possibility of reducing the need for time-consuming digestibility trials with tilapia when formulating least-cost production diets for this species.
\end{abstract}

Digestible energy values: Neutral-detergent fibre: Fish: Tilapia

Diets used for intensive fish production are, as for other farmed animals, formulated on the basis of literature values for metabolizable energy (ME) and digestible energy (DE). However, for several important fish groups such as tilapia, a group of warm-water species, comprehensive tables of energy values are not yet available. In these cases, diets are usually formulated on the basis of feedstuff energy values published for poultry and pigs. Fundamental differences in physiology, feeding behaviour and metabolism between birds, mammals and fish raise doubts over the validity of such energy values for fish production. Even within the class Pisces, differences between fish species are considerable; carnivorous salmonids utilize dietary carbohydrate (Hilton et al. 1982) less well than herbivorous carp (Cyprinus carpio) (Ufodike \& Matty, 1983) or tilapia (Oreochromis niloticus Linn.) (Anderson et al. 1984). These observations suggest a need to determine ME or DE values for feedstuffs appropriate to each species of farmed fish.

Collection of both kidney and gill excretions would be necessary to determine ME values

Present addresses: * The Wellcome Trust, 1 Park Square West, London NW1 4LJ. †Plant and Animal Resources, 5 Wimbridge Close, New Wimpole, Royston, Hertfordshire SG8 5QQ. 
with fish. Metabolism chambers have been constructed for this purpose (Smith, 1976) but the stress involved in their use influences nitrogen balance, and this in turn affects estimates of ME. Correction of ME values to zero $\mathrm{N}$ balance, as practised with birds and mammals, is not currently feasible as the correction factors associated with gains or losses of body $\mathrm{N}$ are not known for fish.

Direct determination of $\mathrm{DE}$ values with fish requires the collection of faeces from water which is free of kidney and gill excretions. To obviate the need for quantitative collection of faeces, an indigestible indicator, usually chromic oxide, has been used (Pappas et al. 1973; Cho et al. 1982). However, the techniques used for collecting faeces have differed between laboratories resulting in variable estimates of DE values. If left to accumulate in aquaria, inaccurate estimates of DE can occur as a result of bacterial action (Smith \& Thorpe, 1976) or leaching of nutrients into the water (Smith et al. 1980), or both. Manual stripping (Austreng, 1978), suction through an anal catheter (Stickney \& Lovell, 1977) or dissection methods may obtain digesta rather than faecal samples, and consequently lead to underestimates of DE values. In addition, the small amounts of faeces available from fish can present technical difficulties in the chemical analysis of this material.

Other problems in determining DE values using fish are similar to those encountered in mammalian digestibility trials: namely the influence of the level of substitution of a reference diet with a test feedstuff, and the effects of adaptation to diet over time (Morgan et al. 1975a).

In view of the importance of tilapia as a human food resource in less-developed countries and the consequent need for accurate feedstuff energy values for the production of this fish, the present study was undertaken to establish methods of obtaining accurate and reproducible DE values in a selection of feedstuffs for this group. These values were then compared with DE values in the literature for trout (Oncorhynchus mykiss), catfish (Ictalurus punctatus) and pigs, and with ME values for poultry, to assess the scale of discrepancy between so-called 'book values' and values measured specifically for tilapia.

Finally, a test was made of the accuracy with which DE values for tilapia could be predicted from chemical analysis of feedstuffs. The resulting regression equations are presented as a possible means of reducing the need for time-consuming digestibility trials with tilapia when estimates are required for the DE values of novel feedstuffs.

\section{MATERIALS AND METHODS}

Tilapia fry were obtained from stocks at the Institute of Aquaculture (University of Stirling) and reared on trout pellets (BP Nutrition UK Ltd; Fry 00-03) to experimental weight in 150 litre aquaria held at $28^{\circ}$, under a photoperiod of light-dark of $16: 8$. The fry were fed to satiation five times daily. Fish to be used in experiments were then transferred to a recirculating-water system composed of sixteen 65 litre tanks maintained at $26-28^{\circ}$. This incorporated two biological filters which detoxified nitrogenous build-up. However, to remove excess $\mathrm{N}$ and replenish water loss due to evaporation, fresh water was fed through the system at a rate of 0.5 litres $/ \mathrm{min}$. The recirculation rate through each tank was 2 litres/min. Water quality variables were maintained as follows: dissolved oxygen $6.0-8.0 \mathrm{mg} / \mathrm{l}$, pH 6.8-7.5, total ammonia less than $0.1 \mathrm{mg} / \mathrm{l}$, nitrate $0-5 \mathrm{mg} / \mathrm{l}$, hardness $19 \cdot 5-21.0 \mathrm{mg}$ calcium carbonate/1.

\section{Digestibility trials}

Preliminary studies indicated that the most feasible way of conducting digestibility trials with tilapia is by separating faeces from water within $5 \mathrm{~min}$ of egestion (Anderson, 1985). This reduces leaching effects to a minimum and eliminates the need for wasteful, in terms of fish numbers, and inaccurate intestinal dissection. Two experiments were conducted: 
Expt 1 examined the effects on digestibility of $(a)$ feedstuff substitution levels in diets and (b) duration of feeding period. Expt 2 comprised a series of digestibility trials on a range of feedstuffs of both plant and animal origin.

\section{Expt 1}

This experiment had a split-plot factorial design with four feedstuff inclusion levels and two periods of feeding. The test feedstuff, soya-bean meal, was substituted for the fish meal in the reference diet (Table 1) at levels of $200,400,600$ and $995 \mathrm{~g} / \mathrm{kg}$ and faecal collection made after 1 and 15 weeks. The sub-plots consisted of six fish weighing 130 (SD 16.9) g at the beginning of the experiment. Feeding rate was $1.0 \%$ of fish live weight/d offered at $09.00,13.00$ and 17.00 hours, with faecal collections taking place over a period of $5 \mathrm{~d}$ using faecal collection chambers. These chambers consisted of a $250 \mathrm{~mm}$ diameter plastic funnel incorporating a $10 \mathrm{~mm}$ mesh screen through which faeces passed to settle in a glass collecting bottle at the apex of the funnel (Anderson, 1985). Individual fish were transferred to these chambers $1 \mathrm{~h}$ after the 09.00 hours meal each day and faeces obtained by removing the collecting bottle at $5 \mathrm{~min}$ intervals over a $2 \mathrm{~h}$ period and passing the contents through a fine mesh. Retained faeces were pooled for each fish, transferred to Petri dishes and dried at $105^{\circ}$ to constant weight. Subsequently they were ground with a pestle and mortar and stored in airtight tubes over a desiccant until required for analysis.

\section{Expt 2}

Digestibility trials were conducted on sixteen feedstuffs and a reference diet (Table 2) using groups of twelve male tilapia (mean weight 45 (SD 11.3) g) for each feedstuff. The rate of substitution of the test feedstuff in the reference diet was $600 \mathrm{~g} / \mathrm{kg}$. The reference diet and diets containing wheat middlings and meat-and-bone meal were evaluated with six replicate groups of fish, but all other feedstuffs were evaluated with three replicate groups. To avoid carry-over effects, each digestibility trial was separated by a period of $7 \mathrm{~d}$, during which experimental fish received a commercial trout diet. Fish were randomly allocated between the experimental tanks in different trials. Each diet was given for a period of $28 \mathrm{~d}$ before faeces were collected by siphoning from tanks. Feeding rates were $2 \%$ of the group liveweight/d presented in three equal portions daily at $09.00,13.00$ and 17.00 hours. Faeces collection commenced $1 \mathrm{~h}$ after the 09.00 hours feed and continued at 5 min intervals for $2 \mathrm{~h}$. Faeces from each group were dried, ground and stored as in Expt 1.

\section{Diets}

The diets used in the experiments are detailed in Table 1. The composition of each individual feedstuff is given in Table 2 . Ingredients were processed where necessary using a laboratory hammermill to pass a $1 \mathrm{~mm}$ mesh screen and mixed using a food mixer (A200; Hobart Ltd, London). Water was added to form a paste which was extruded using a $3 \mathrm{~mm}$ die. The resulting strings of diet were laid on trays, dried at $40^{\circ}$ for $14 \mathrm{~h}$ in a force-draught oven and broken in a food processor. After passing through a $2.8 \mathrm{~mm}$ sieve, diets were stored in plastic bags at $-20^{\circ}$ until required.

\section{Analytical methods}

Diets. Moisture, crude protein $(\mathrm{N} \times 6.25 ; \mathrm{CP})$, petroleum (bp. 40-60 $)$ extract, ash and crude fibre were determined on individual test feedstuffs and complete diets using the methods described by Ministry of Agriculture, Fisheries and Food (1973). Procedures for acid-detergent fibre and neutral-detergent fibre (NDF) were those described by Goering \& Van Soest (1970).

Available carbohydrate (AC) was measured using the method of Bolton (1960), whereby starch in each feedstuff $(1.5 \mathrm{~g})$ was converted to glucose using an amyloglucosidase $(E C$ 


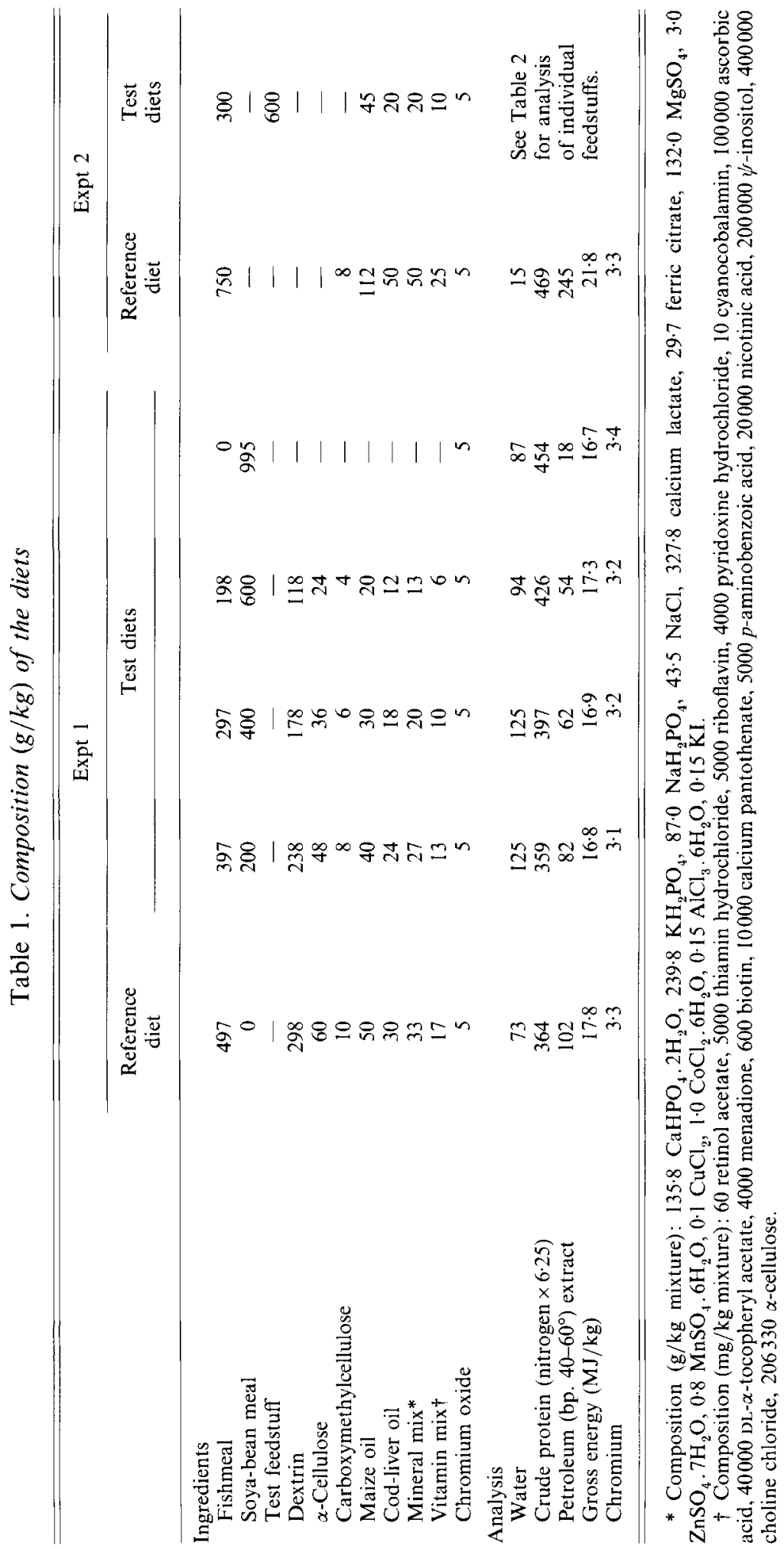


PREDICTION OF DIGESTIBLE ENERGY FOR FISH

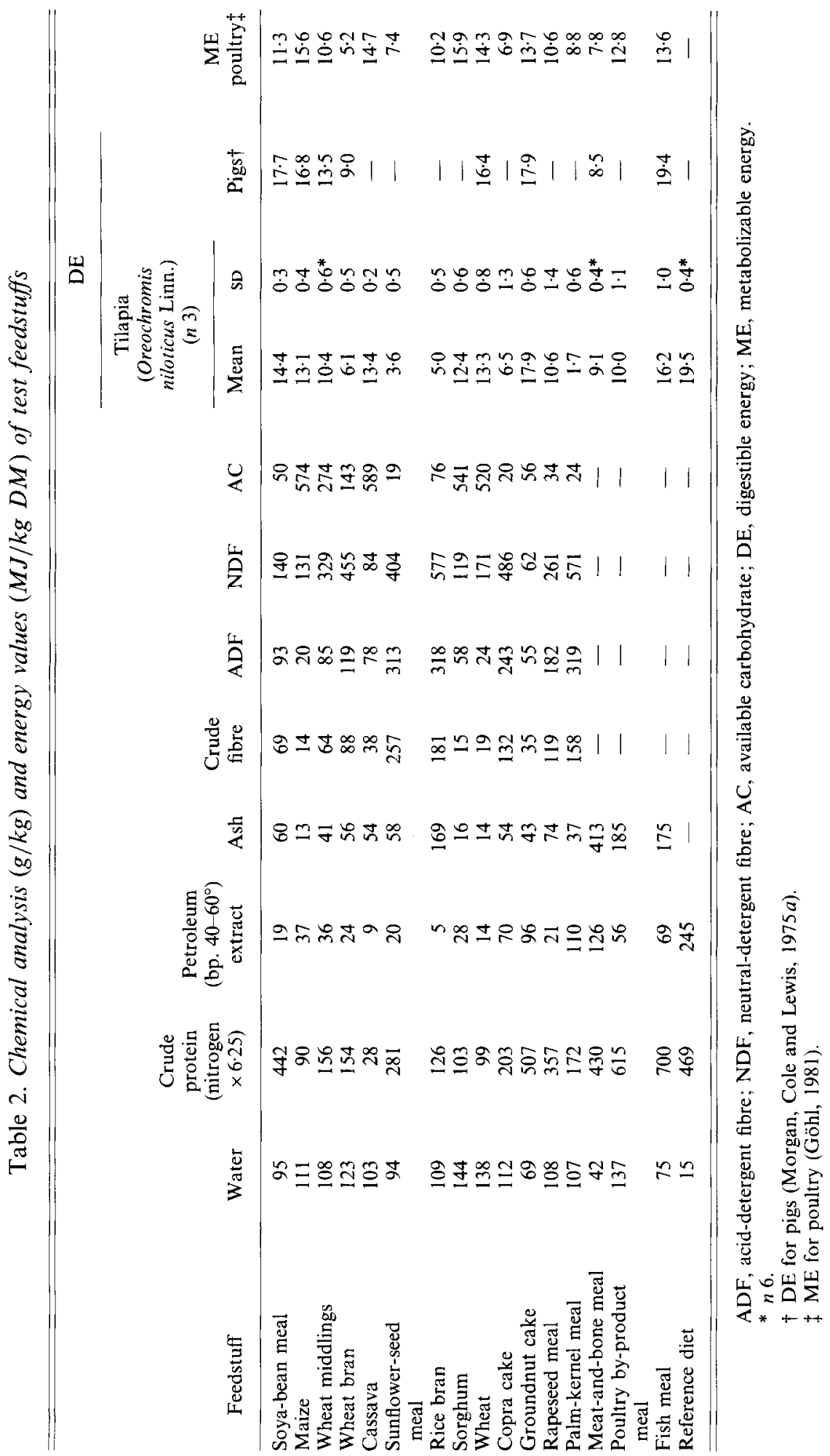


$3.2 .1 .3 ; 1 \mathrm{ml}$ solution containing $1.0 \mathrm{mg}$; activity $5000-10000 \mathrm{IU} / \mathrm{g}$ ) derived from Rhizopus mould (Sigma Chemical Co Ltd). The resulting glucose was measured using a glucose analyser (Model 27; Yellow Springs Instruments Ltd, Ohio, USA). In this instrument, membrane-bound glucose oxidase $(E C$ 1.1.3.4) converts glucose to hydrogen peroxide and this is then determined electrometrically.

Chromium was determined with a Perkin Elmer 303 atomic absorption spectrophotometer (detection wavelength $357.9 \mathrm{~nm}$ ) using an air-acetylene flame after digestion of feedstuff samples with concentrated sulphuric acid and a selenium catalyst (Thomson and Capper Ltd, Cheshire). Gross energy values were measured using an adiabatic bomb calorimeter (Gallenkamp and Co. Ltd).

Faeces. Standard techniques for measuring dietary energy, $\mathrm{N}$ and $\mathrm{Cr}$ were unsuitable for faecal analysis because of the small samples of this material (150 mg dry matter (DM)) obtainable from each trial. Existing analytical techniques were, therefore, modified to permit duplicate microassays of the material that was available as described later and by Anderson (1985).

$\mathrm{Cr}$ and $\mathrm{N}$ were measured in the same $\mathrm{H}_{2} \mathrm{SO}_{4}-\mathrm{Se}$ digest of $40 \mathrm{mg}$ faeces. Cr was measured in one portion of the diluted digest by atomic absorption spectrophotometry (as for the diets) whilst $\mathrm{N}$ was determined in another portion using a dichloroisocyanurate reaction (Crooke \& Simpson, 1971) in an AutoAnalyzer (Model 11; Technicon Instruments Corporation, Tarrytown, NY, USA), Digests $(0.32 \mathrm{ml} / \mathrm{min})$ were diluted in the AutoAnalyzer manifold in two stages at an overall rate of $1: 23 \cdot 2$. Salicylate solution $(850$ $\mathrm{g}$ sodium salicylate $/ 1$ and $6 \mathrm{~g}$ sodium nitroprusside/1) and cyanurate solution ( $24 \mathrm{~g}$ sodium hydroxide $/ 1$ and $5 \mathrm{~g}$ sodium dichloroisocyanurate/l) were added at rates of 0.32 and $0 \cdot 16$ $\mathrm{ml} / \mathrm{min}$ respectively. After heating in a delay coil at $37^{\circ}$, transmittance was measured in a $15 \mathrm{~mm}$ flow cell at $660 \mathrm{~nm}$. Duplicate samples of faeces were analysed for each replicate group of fish.

Gross energy values were determined by chemical oxidation of duplicate $20 \mathrm{mg}$ faecal samples with potassium dichromate $\left(0 \cdot 25 \mathrm{M}-\mathrm{K}_{2} \mathrm{Cr}_{2} \mathrm{O}_{7}\right)$, reaction of non-utilized dichromate with excess $0.83 \mathrm{M}$-potassium iodide and titration of the liberated iodine with $0.3 \mathrm{M}$ $\mathrm{Na}_{2} \mathrm{~S}_{2} \mathrm{O}_{3} .5 \mathrm{H}_{2} \mathrm{O}$ (O'Shea \& Maguire, 1962). However, to ensure complete oxidation of fibrous residues, solutions were boiled for $5 \mathrm{~min}$ after addition of the $\mathrm{K}_{2} \mathrm{Cr}_{2} \mathrm{O}_{7}$ solution. Incomplete oxidation of $\mathrm{CP}$ occurs to an increasing extent as $\mathrm{CP}$ levels $(\mathrm{g} / \mathrm{kg} \mathrm{DM})$ in materials increase. Thus, a correction equation was computed using feedstuff energy values found by bomb calorimetry. The oxidation coefficient $(C)$ expressed in $\mathrm{ml} 0.25 \mathrm{M}$ $\mathrm{K}_{2} \mathrm{Cr}_{2} \mathrm{O}_{7} / \mathrm{kJ}$ was given by:

$$
\begin{gathered}
C=5.30-0.00196 \mathrm{CP} . \\
\left(r^{2} 0.83, P<0.001\right)
\end{gathered}
$$

Gross energy values were found by dividing the volume of $\mathrm{K}_{2} \mathrm{Cr}_{2} \mathrm{O}_{7}$ solution used to oxidize the faecal sample by $C$. The correction equation is specific to the feedstuffs examined in the present study and is different from that quoted by O'Shea \& Maguire (1962), which results in predicted energy values that are on average $1.61 \mathrm{MJ} / \mathrm{kg} \mathrm{DM}$ lower for these feedstuffs.

\section{Calculation of $D E$ values}

$\mathrm{DE}$ values $(\mathrm{MJ} / \mathrm{kg} \mathrm{DM})$ were calculated using the formula:

$$
\mathrm{DE}=\text { Energy in diet }-\left(\frac{\mathrm{Cr} \text { in diet }}{\mathrm{Cr} \text { in faeces }} \times \text { energy in faeces }\right)
$$

where $\mathrm{Cr}$ is a concentration $(\mathrm{g} / \mathrm{kg} \mathrm{DM})$. Feedstuff $\mathrm{DE}$ values were determined by difference from $\mathrm{DE}$ values for test and reference diets. 


\section{Statistical procedures}

The results of Expt 1 were subjected to an analysis of variance for split-plot factorial designs and differences between means were tested for significance using Tukey's test (Kirk, 1968). Single- and multiple-regression equations were calculated from the values in Expt 2 using the procedures of Snedecor \& Cochran (1972), with DE as the dependent variable and the various chemical measures as independent variables.

\section{RESULTS}

Expt 1. Effects of level of substitution in a reference diet and length of feeding period on test feedstuff $D E$ value

Fig. 1 shows that as the level of substitution of soya-bean meal for the reference diet was increased, the DE value was reduced and DE values obtained after a 15-week adaptation period were higher than those obtained after 1 week. Split-plot factorial analysis of variance for these values is given in Table 3. Tukey's multiple-comparison test showed that $\mathrm{DE}$ values for soya-bean meal were significantly depressed $(P<0.05)$ only when this feedstuff was given on its own as compared with when it was given as a component of a complete diet. This suggests that whilst adaptation to diet is an important factor in digestibility trials with fish, there is comparatively little effect of test feedstuff substitution level between 200 and $600 \mathrm{~g} / \mathrm{kg}$.

\section{Expt 2. DE values of feedstuffs}

The measured DE values are listed in Table 2 together with the results of chemical analyses of the feedstuffs, literature DE values for these feedstuffs determined with pigs and ME values quoted for poultry. The reproducibility of the results was good and although the use of six replications with wheat middlings, meat-and-bone meal and the reference diet led to marginally reduced standard deviations of estimates, three replications appeared satisfactory. The DE estimate for palm-kernel meal was, however, substantially lower than expected and may be inaccurate.

\section{Regression of DE values on chemical measures of feedstuffs}

Linear-regression equations were calculated using values for the thirteen plant-derived feedstuffs (Table 4). The single most accurate predictor of DE (MJ/kg DM) was NDF (g/kg DM).

The equation was:

$$
\begin{gathered}
\mathrm{DE}=16.88-0.021 \mathrm{NDF} . \\
\left(r^{2} 0 \cdot 87, \text { residual standard deviation }(\mathrm{RSD}) 1 \cdot 81, P<0.001\right)
\end{gathered}
$$

NDF accounted for so much of the variation in DE that the use of additional chemical measures such as petroleum (bp. $40-60^{\circ}$ ) extract in multiple-regression equations already containing NDF failed to improve the accuracy of prediction to any significant extent. However, when NDF was excluded, useful multiple-regression equations could be calculated by including other variables $(\mathrm{g} / \mathrm{kg}$ DM) such as $\mathrm{CP}$ and $\mathrm{AC}$. The most useful of these multiple regressions predicts $\mathrm{DE}(\mathrm{MJ} / \mathrm{kg} \mathrm{DM})$ as follows:

$$
\begin{gathered}
\mathrm{DE}=0.034 \mathrm{CP}+0.022 \mathrm{AC}-3.5 \\
\left(r^{2} 0.87, \mathrm{RSD} 1.93, P<0.001\right)
\end{gathered}
$$




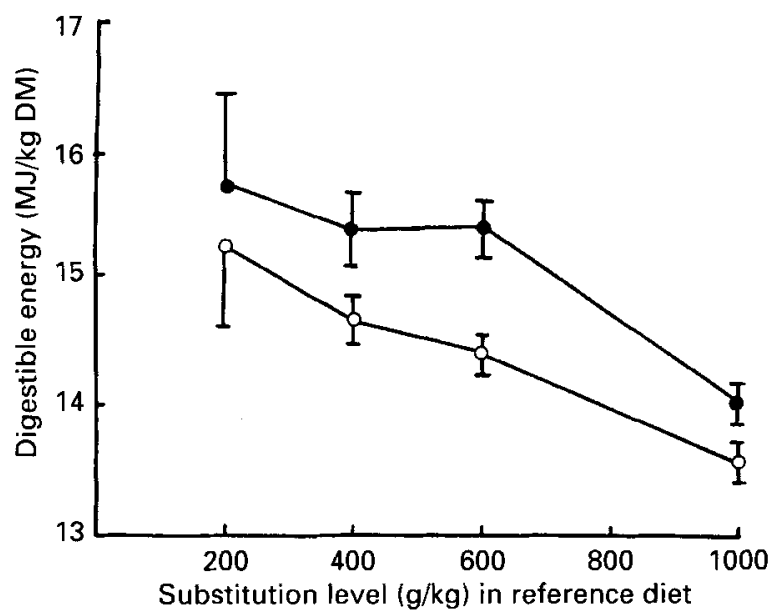

Fig. 1. Expt 1. The digestible energy value of soya-bean meal determined at different substitution levels in a reference diet fed to tilapia (Oreochromis niloticus Linn.). Values determined after adaptation periods of 1 week $(O)$ and 15 weeks $(O)$. Values are means with their standard errors $(n 6)$ represented by vertical bars. DM, dry matter. For details of diets and procedures, see pp. 39 42 .

Table 3. Expt 1. Split-plot analysis of variance for effects of soya-bean meal level and feeding period on the digestible energy value of soya-bean meal for tilapia (Oreochromis niloticus Linn.)

\begin{tabular}{|c|c|c|c|c|}
\hline Source of variation & $\begin{array}{l}\text { Sum of } \\
\text { squares }\end{array}$ & $\mathrm{df}$ & $\begin{array}{l}\text { Mean } \\
\text { square }\end{array}$ & $F$ ratio \\
\hline Between subjects & $1182 \cdot 7$ & 23 & - & \\
\hline A (soya-bean meal level) & $468 \cdot 5$ & 3 & $156 \cdot 2$ & $4 \cdot 37^{*}$ \\
\hline $\begin{array}{l}\text { Subjects within groups } \\
\text { (main plot error) }\end{array}$ & $714 \cdot 2$ & 20 & $35 \cdot 7$ & \\
\hline Within subjects & $363 \cdot 8$ & 24 & - & \\
\hline B (feeding period) & 113.9 & 1 & 113.9 & $10 \cdot 37^{* *}$ \\
\hline $\mathrm{A} \times \mathrm{B}$ & $30 \cdot 3$ & 3 & $10 \cdot 1$ & 0.92 \\
\hline $\begin{array}{l}\text { B } \times \text { subjects within groups } \\
\text { (sub-plot error) }\end{array}$ & $219 \cdot 6$ & 20 & $11 \cdot 0$ & \\
\hline Total & $1546 \cdot 5$ & 47 & & \\
\hline
\end{tabular}

$$
{ }^{*} P<0.05,{ }^{* *} P<0.01 \text {. }
$$

\section{DISCUSSION}

The evidence of the present study suggests that the maximum substitution level of feedstuffs in experimental diets is $600 \mathrm{~g} / \mathrm{kg}$ because above this level estimates of DE can be depressed (Fig. 1). Further, there was evidence suggesting that tilapia adapt to their diet with time in a way that increases the observed DE of test feedstuffs (Fig. 1, Table 3). Such adaptation could be caused by diet-induced increases in the activity of digestive enzymes (e.g. amylase EC 3.2.1.1) as found in the tilapia Sarotherodon mossambicus (Nagase, 1964). Noue et al. (1980) suggested that complete adaptation to diets occurred after $3 \mathrm{~d}$ in rainbow trout (Oncorhynchus mykiss) but the results of the present study suggest that adaptation of tilapias may take considerably longer. Ideally, the period over which DE values should be measured would correspond to the normal growing period of 3-5 months used during the 
Table 4. Expt 2. Prediction of digestible energy values $(M J / \mathrm{kg}$ dry matter $(D M))$ of plant-derived feedstuffs from chemical analyses $(\mathrm{g} / \mathrm{kg} \mathrm{DM})$

\begin{tabular}{|c|c|c|c|c|c|c|}
\hline \multirow{2}{*}{$\begin{array}{l}\text { Independent } \\
\text { variable }\end{array}$} & \multirow[b]{2}{*}{ Intercept } & \multicolumn{2}{|c|}{ Slope } & \multirow[b]{2}{*}{$r^{2}$} & \multirow[b]{2}{*}{ RSD } & \multirow{2}{*}{$\begin{array}{l}\text { Statistical } \\
\text { significance }\end{array}$} \\
\hline & & Mean & SE & & & \\
\hline $\begin{array}{l}\text { Crude protein } \\
(\text { nitrogen } \times 6.25)\end{array}$ & $7 \cdot 97$ & $0 \cdot 008$ & $0-009$ & 0.07 & $4 \cdot 88$ & NS \\
\hline $\begin{array}{l}\text { Petroleum (bp. } 40-60^{\circ} \text { ) } \\
\text { extract }\end{array}$ & $10 \cdot 60$ & -0.017 & $0 \cdot 040$ & 0.02 & $5 \cdot 03$ & NS \\
\hline Ash & $12 \cdot 37$ & -0.042 & 0.030 & $0 \cdot 15$ & $4 \cdot 68$ & NS \\
\hline Crude fibre & $14 \cdot 84$ & -0.049 & 0.010 & 0.69 & $2 \cdot 83$ & $* * *$ \\
\hline $\begin{array}{l}\text { Acid-detergent } \\
\text { fibre }\end{array}$ & $15 \cdot 33$ & -0.033 & 0.006 & 0.76 & $2 \cdot 47$ & $* * *$ \\
\hline $\begin{array}{l}\text { Neutral-detergent } \\
\text { fibre }\end{array}$ & $16 \cdot 88$ & $-0 \cdot 021$ & 0.002 & 0.87 & $1 \cdot 81$ & $* * *$ \\
\hline $\begin{array}{l}\text { Available } \\
\text { carbohydrate }\end{array}$ & $7 \cdot 76$ & 0.008 & $0 \cdot 005$ & 0.22 & $4 \cdot 47$ & NS \\
\hline
\end{tabular}

NS, not significant $(P>0 \cdot 05)$; RSD, residual standard deviation. $* * * P<0.001$.

intensive culture of tilapias. However, the conduct of digestibility trials over such a long period would not usually be practicable. In the present experiments, a period of $28 \mathrm{~d}$ was used and the DE values reported may, therefore, be marginally lower than would be apparent under production conditions.

In the second part of the present work, DE values were measured in a range of feedstuffs for tilapia. Feedstuffs such as soya-bean meal, groundnut cake and fish meal were found to have the highest $\mathrm{DE}$ values of those tested, providing evidence that protein is readily digested and absorbed in tilapias. In contrast to salmonids (Hilton et al. 1982), the feedstuffs containing high levels of carbohydrate (maize, cassava, sorghum and wheat) also had relatively high DE values, supporting the findings of Anderson et al. (1984) that tilapias utilize carbohydrates effectively for growth. The lowest DE values were found in feedstuffs containing high levels of fibre, such as wheat bran, sunflower-seed meal, rice bran and copra cake. The meat-and-bone meal used in the present study had a higher ash content than is normally quoted for this material, and the rice bran used had higher levels of crude fibre than good-quality rice bran (Göhl, 1981), indicating, respectively, the presence of a greater quantity of bones, and contamination with rice hulls. All the other feedstuff samples had chemical compositions which were typical for those materials and their DE values may be regarded as being representative and reliable. The exception was palm-kernel meal which produced poorly-bound faeces, and a very low DE value which is probably inaccurate.

DE values determined for the animal-product feedstuffs meat-and-bone meal, poultry by-product meal and fish meal, were lower than those reported for trout (Cho et al. 1982) of $15 \cdot 0,13 \cdot 9$ and $18 \cdot 8 \mathrm{MJ} / \mathrm{kg}$ DM respectively. In contrast, values determined for maize, wheat middlings and rapeseed meal were much higher than values reported for trout of 6.6 , 7.6 and $8.1 \mathrm{MJ} / \mathrm{kg}$ DM. DE values of plant feedstuffs determined with tilapia were also found to be generally higher than those quoted for catfish (National Research Council, 1977). In comparison with DE values for pigs (Morgan et al. 1975a), the values for tilapia obtained in the present study were all lower with the exception of that for meat-and-bone meal. Poultry ME values (Göhl, 1981) are lower than the measured DE values for tilapia with respect to the high-protein feedstuffs meat-and-bone meal, fish meal, soya-bean meal 
and groundnut meal. Thus, the use of poultry ME values in formulating diets for warmwater fish as suggested by the National Research Council (1977) would underestimate the energy value of these feedstuffs for tilapia. By contrast, poultry ME values for rice bran, sunflower-seed meal, sorghum and maize (Göhl, 1981) are higher than the DE values determined for tilapia. Clearly, poultry $\mathrm{ME}$ values and tilapia $\mathrm{DE}$ values are poorly correlated and the use of poultry ME values to formulate diets for tilapia should be discontinued.

The third part of the present work assesses the accuracy with which DE values for tilapia can be predicted from the chemical composition of feedstuffs. Preliminary analyses revealed that the predictive accuracy of the equations was always greater if values for the animalproduct feedstuffs were excluded from the regressions. This is because the single most powerful predictor of DE was found to be fibre, which is absent in meat-and-bone meal, poultry by-product meal and fish meal. Accordingly, the equations reported here should only be used to predict the DE values of plant-product feedstuffs. Over 300 regression equations were computed for the thirteen plant-product feedstuffs, but only the two most useful and accurate are reported here. Others can be computed from the values in Table 2, if required.

This general approach has already been used to predict the energy values of feedstuffs for poultry (Carpenter \& Clegg, 1956), pigs (Morgan et al. 1975b) and ruminants (Schneider et al. 1951; Ministry of Agriculture, Fisheries and Food, 1975). With pigs, fibre (measured as crude fibre, cellulose or modified acid-detergent fibre) was found to be the best single predictor of ME or DE (Drennan \& Maguire, 1970; Morgan et al. 1975a,b). However, the fibre-DE relationship was only valid for cereals. For other feedstuffs there is greater variation in fat and protein, and a more complex relationship to DE. Using multipleregression analysis, the best estimate of DE for a wider range of feedstuffs was an equation which included CP, acid-diethyl ether extract and N-free extract (NFE) (Morgan et al. 1975b). For poultry feedstuffs, a similar approach was taken (Carpenter \& Clegg, 1956) but ME prediction was improved by replacing NFE in the equation with 'starch + sugars'. NFE includes carbohydrates such as starches, soluble sugars and part of the hemicellulose fraction of plant cell walls (Bolton, 1960). It was suggested that the equation including 'starch + sugars' is a more accurate measure of ME for poultry because they are less able to digest (and hence obtain energy from) hemicellulose than pigs.

With fish, it is clear that plant cell walls are completely indigestible (Stickney \& Shumway, 1974; Van Dyke \& Sutton, 1977) and that, as with poultry, a direct measure of $\mathrm{AC}$ is preferable to NFE as a predictor of DE (present values). These observations presumably explain the high correlation of DE values with NDF and AC observed for plant-derived feedstuffs in the present study.

In previous studies with pigs, when the level of dietary fat was included as a variable in multiple-regression equations, it was found to improve the accuracy of DE prediction (Morgan et al. 1975b). This was not found to be the case for tilapia in the present study. Numerous regressions were computed using petroleum (bp. 40-60 ) extract as an independent variable, but this never significantly reduced the RSD of equations already containing fibre, $\mathrm{AC}$ or protein. Even when petroleum (bp. $\left.40-60^{\circ}\right)$ extract was used as the only independent variable it was a poor predictor of DE. In contrast, $\mathrm{CP}$ and $\mathrm{AC}$ accurately predicted DE when combined in multiple regressions, even when fibre measures were not included (equation 2). Whilst this is a useful addition to the fibre regressions, analysis of ingredients for $\mathrm{AC}$ would not, of course, be as convenient on a routine basis as would the simple measurement of NDF.

In summary, it is apparent that the absence of reliable energy values for tilapia in the literature acts as a constraint on feed manufacturers wishing to produce competitive, least- 
cost formulations for this species. From the present study it is also clear that the measurement of DE values of feedstuffs for tilapia requires considerable technical care, and the use of micro-analytical procedures. This is due primarily to the small samples of faeces obtainable in feeding trials, and the influence on DE of test feedstuff substitution level and adaptation of this fish to diets. These difficulties make it unrealistic for manufacturers of commercial diets for tilapia to undertake routine digestibility trials of locally-available feedstuffs in the developing countries where tilapia are farmed. This is a serious limitation to the intensive farming of this species, given the widespread and increasing importance of tilapia as a human food source in the Third World. It is hoped, therefore, that the equations resulting from the present study will provide a means of predicting the DE values of feedstuffs from simple measures of their composition, so reducing the need for digestibility trials, and improving the basis on which compound diets are formulated for tilapia.

This work formed part of the PhD research of J.A., which was supported by the UK Overseas Development Administration, through the Overseas Development Natural Resources Institute.

\section{REFERENCES}

Anderson, J. (1985). Digestible energy and carbohydrates in the nutrition of tilapia (Oreochromis niloticus Linn.). PhD Thesis, University of Aston, Birmingham.

Anderson, J., Jackson, A. J., Matty, A. J. \& Capper, B. S. (1984). Effects of dietary carbohydrate and fibre on the tilapia Oreochromis niloticus (Linn.). Aquaculture 37, 303-314.

Austreng, E. (1978). Digestibility determination in fish using chromic oxide marking and analysis of contents from different segments of the gastrointestinal tract. Aquaculture 13, 265-272.

Bolton, W. (1960). The determination of digestible carbohydrate in poultry foods. Analyst 85, 189-192.

Carpenter, K. J. \& Clegg, K. M. (1956). The metabolisable energy of poultry feeding stuffs in relation to their chemical composition. Journal of the Science of Food and Agriculture 7, 45-51.

Cho, C. Y., Slinger, S. J. \& Bayley, H. S. (1982). Bioenergetics of salmonid fishes: Energy intake, expenditure and productivity. Comparative Biochemistry and Physiology 73B, 25-41.

Crooke, W. M. \& Simpson, W. E. (1971). Determination of ammonium in kjeldahl digests of crops by an automated procedure. Journal of the Science of Food and Agriculture 22, 9-10.

Drennan, P. \& Maguire, M. F. (1970). Prediction of the digestible and metabolisable energy content of pig diets from their fibre content. Irish Journal of Agricultural Research 9, 197-202.

Goering, H. K. \& Van Soest, P. J. (1970). Forage Fiber Analyses (Apparatus, Reagents, Procedures and Some Applications). Agricultural Handbook of the United States Department of Agriculture no. 379. Washington, DC: Agricultural Research Service, US Department of Agriculture.

Göhl, B. (1981). Tropical Feeds. Rome: FAO.

Hilton, J. W., Atkinson, J. L. \& Slinger, S. J. (1982). Maximum tolerable level, digestion and metabolism of Dglucose (Cerelose) in rainbow trout (Salmo gairdneri) reared on a practical trout diet. Canadian Journal of Fisheries and Aquatic Sciences 39, 1229-1234.

Kirk, R. E. (1968). Experimental Design: Procedures for the Behavioural Sciences. Monterey, California: Brooks/Cole Publishing Company.

Ministry of Agriculture, Fisheries and Food (1973). Analysis of Agricultural Materials. Technical Bulletin no. 27. London: H.M. Stationery Office.

Ministry of Agriculture, Fisheries and Food (1975). Energy Allowances and Feeding Systems for Ruminants. Technical Bulletin no. 33. London: H.M. Stationery Office.

Morgan, D. J., Cole, D. J. A. \& Lewis, D. (1975a). Energy values in pig nutrition. I. The relationship between digestible energy, metabolisable energy and total digestible nutrient values of a range of feedstuffs. Journal of Agricultural Science, Cambridge 84, 7-17.

Morgan, D. J., Cole, D. J. A. \& Lewis, D. (1975 b). Energy values in pig nutrition. II. The prediction of energy values from dietary chemical analysis. Journal of Agricultural Science, Cambridge 84, 19-27.

Nagase, G. (1964). Contributions to the physiology of digestion in Tilapia mossambica Peters: digestive enzymes and the effects of diets on their activity. Zeitschrift für Vergleichende Physiologie 49, 270-284.

National Research Council (1977). Nutrient Requirements of Warm Water Fishes. Washington, DC: National Academy of Sciences.

Noue, de la, J., Choubert, G., Pagniez, B., Blanc, J.-M. \& Luquet, P. (1980). Digestibilité chez la truite arc-enciel (Salmo gairdneri) lors de l'adaptation à un nouveau régime alimentaire (Digestibility in rainbow trout (Salmo gairdneri) after adaptation to a new dietary regime). Canadian Journal of Fisheries and Aquatic Sciences 37, $2218-2224$. 
O'Shea, J. \& Maguire, M. F. (1962). Determination of calorific value of feedstuffs by chromic acid oxidation. Journal of the Science of Food and Agriculture 13, 530-534.

Pappas, C. J., Tiemeier, O. W. \& Deyoe, C. W. (1973). Chromic sesquioxide as an indicator in digestion studies on channel catfish. Progressive Fish-Culturist 35, 97-98.

Schneider, B. H., Lucas, H. L., Pavlech, H. \& Cipolloni, M. A. (1951). Estimation of the digestibility of feeds from their proximate composition. Journal of Animal Science 10, 706-713.

Smith, M. A. K. \& Thorpe, A. (1976). Nitrogen metabolism and trophic input in relation to growth in freshwater and saltwater Salmo gairdneri. Biological Bulletin 150, 139-151.

Smith, R. R. (1976). Metabolisable energy of feedstuffs for trout. Feedstuffs 48 no. 23, 16-21.

Smith, R. R., Peterson, M. L. \& Allred, A. C. (1980). Effect of leaching on apparent digestion coefficients of feedstuffs for Salmonids. Progressive Fish-Culturist 42, 195-199.

Snedecor, G. W. \& Cochran, W. G. (1972). Statistical Methods, 6th ed. Ames: Iowa State University Press.

Stickney, R. R. \& Lovell, R. T. (1977). Nutrition and feeding of channel catfish. Southern Cooperatives Series Bulletin 218, 1-67.

Stickney, R. R. \& Shumway, E. E. (1974). Occurrence of cellulase activity in the stomach of fishes. Journal of Fish Biology 6, 779-790.

Ufodike, E. B. C. \& Matty, A. J. (1983). Growth responses and nutrient digestibility in mirror carp (Cyprinus carpio) fed different levels of cassava and rice. Aquaculture 31, 41-50.

Van Dyke. J. M. V. \& Sutton, D. L. (1977). Digestion of duckweed (Lemna sp.) by the grass carp (Ctenopharygodon idella). Journal of Fish Biology 11, 273-278. 